\title{
Viewpoint
}

\section{Supplying commercial biomedical companies from a human tissue bank in an NHS hospital-a view from personal experience}

\author{
N Gray, C Womack, S J Jack
}

\begin{abstract}
NHS histopathology laboratories are well placed to develop banks of surgically removed surplus human tissues to meet the increasing demands of commercial biomedical companies. The ultimate aim could be national network of non-profit making NHS tissue banks conforming to national minimum ethical, legal, and quality standards which could be monitored by local research ethics committees. The Nuffield report on bioethics provides ethical and legal guidance but we believe that the patient should be fully informed and the consent given explicit. Setting up a tissue bank requires enthusiasm, hard work, and determination as well as coordination between professionals in the NHS trust and in the commercial sector. The rewards are exiting new collaborations with commercial biomedical companies which could help secure our future. (f Clin Pathol 1999;52:254-256)
\end{abstract}

Keywords: human tissue bank; biomedical companies; ethics

Recent technological developments have meant that it is now possible to make more efficient use of human cells, tissues, and organs for drug discovery research. ${ }^{1}$ There is also increasing pressure on commercial biomedical research organisations to look at alternatives to animal experiments. This is partly owing to the activities of animal welfare groups, some of whom, with scientific support, have provided a positive encouragement to commercial biomedical companies and the general public. ${ }^{2}$ Although biomedical companies already carry out some testing of their drug candidates on human tissues, the range of tissues available to these companies is generally limited. ${ }^{3}$ In the United Kingdom, biomedical companies are becoming aware that the largest store of human tissue is to be found in NHS hospitals, where thousands of samples, including whole organs, are removed daily. The vast majority of diseased tissues are sent to NHS histopathology departments for analysis before being stored as paraffin blocks for a minimum of 10 years ${ }^{4}$ and surplus is discarded. The challenge
Table 1 Nuffield report and tissue banks

Tissue removed during an operation may be used for research alternatively a researcher may obtain tissue from a tissue bank or some other source. The researcher may be a commercial enterprise.

Removal of tissue from the dead for ethically acceptable purposes may be regarded as lawful as long as consent has been obtained.

Consent is not required for left over tissue as long as it is anonymised.

Human tissue research may take place at pharmaceutical or biotechnology companies.

Tissue to be used for research purposes should only be obtained from approved intermediaries.

There is an onus on the researcher to ensure that any proposed uses of human tissue are ethically acceptable.

Ethics committee approval is not required where: anonymised surplus surgically removed tissue is concerned anonymised archived material is used

DNA is being extracted.

is to match the increasing requirements of biomedical researchers for viable human tissue and the wishes of the patient in a way that is ethical, legal, and beneficial to all the parties.

In establishing a successful tissue bank at Peterborough Hospitals NHS Trust under an enterprise division of pathology, Peterborough Cellular Pathology Services (PCPS), we have considered carefully the following aspects.

\section{Nuffield report}

The Nuffield Council established a working party, under the chairmanship of Dame Rosalind Hurley, to clarify the legal position and to draw up some recommendations on the associated ethics. The Nuffield report was published in April 1995. ${ }^{5}$ The points relevant to a tissue bank in an NHS trust are summarised in table 1 .

\section{Local ethical issues and consent}

It is clear from the recommendations of the Nuffield Report that an NHS histopathology laboratory, with ready access to "discarded" human tissue, may set up a tissue bank with a view to supplying commercial biomedical and pharmaceutical companies. The report recommends that "the consent [to medical treatment involving the removal of tissue] should be taken to include consent also to the subsequent disposal or storage of the tissue and to any further acceptable use provided that this is regulated by appropriate ethical, legal and 
professional standards"; this we consider a rather blanket consent. The Royal College of Physicians has recommended that human tissue supply does not require the consent of the patient provided the tissue is "anonymised." Anonymity is maintained by consultant histopathologists in this department acting as medical intermediaries ${ }^{5}$ separating non-commercial procurement and the commercial use of human tissue.

Despite adherence to the well considered findings of the Nuffield report, initially we were apprehensive about the commercial nature of our proposed tissue bank even though we are non-profit making. We felt that patients should understand fully what we were intending to do with their surplus tissues and so we designed and produced information sheets to be used with a consent form that is explicit. The consent form makes it clear, among other things, that the surplus tissue is collected for research by a commercial biomedical company that will be charged on a cost recovery basis for the work required to collect, store, and prepare the tissue which is separate from any diagnostic procedure. The consent form also states that the patient waives any right to receive payment. We appreciate that patients do not always clearly understand the use of the term "tissue." However, consent is obtained prospectively, separate from the consent for surgery. This has now been made easier with the appointment of dedicated research nurses who can provide counselling which is sometimes necessary to deal with the sensitive nature of this project. The consent form and information sheet are subject to regular review.

From the outset, the activities of the tissue bank have been approved and, furthermore, are monitored by the local research ethics committee (North West Anglia Health Authority). This too is a recommendation of the Nuffield Working Party on the ground that the Peterborough Hospitals NHS Trust is charging recovery costs although in the next paragraph of the report it is stated that research ethics committee approval is not needed if the research uses anonymised left over tissue.

Most of our tissue bank activities revolve around collection of fresh surgically removed human tissue from operating theatres. This, in our experience, yields the most appropriate source of viable tissue in terms of function and antigenicity.

\section{Legal aspects}

Under the Human Organ Transplants (Unrelated Persons) Regulations 1989 it is illegal to sell human organs intended for transplant, although it is legal to recover costs. We are not aware of any similar legislation relating to tissue removed surgically for diagnosis or treatment. The Nuffield report states that use of human tissue without any therapeutic intent, direct or indirect, is unacceptable but it is not illegal. The further question of ownership of surgically removed tissue is controversial ${ }^{78}$ and not settled in law in the United Kingdom. In a landmark case, ${ }^{9}$ the Supreme Court of California found that a patient with hairy cell leukae- mia had no rights of property to cells taken from his body. The physicians involved were quick to realise commercial potential; a cell line was produced and subsequently patented. In judgement the Supreme Court also stated that the question as to whether or not the physicians were in breach of duty in not obtaining informed consent from their patient would need to go to trial. No answer was forthcoming as there was an out of court settlement. For practical purposes surgically removed tissue is considered to be discarded-that is, wastebut this is not a legal definition.

There are other important legal issues to consider when dealing with commercial biomedical companies. We have employed the services of a commercial lawyer to draw up a tissue supply agreement which separates the tissue bank from any other activity undertaken with that company. This arrangement emphasises that, although human tissue may not be bought or sold, there is a considerable amount of time, effort, and material resource expended in the collecting, preparing, storage, and supplying of human tissues for research purposes. The histopathology department is obliged to recover these as well as indirect costs on behalf of the trust and the NHS. ${ }^{10}$ The tissue supply agreement provides a legally binding contract that covers, among other things, recovery of costs, limitation of liability to the trust, anonymity issues, quality issues, and a degree of control as to the nature of use of the tissue by the commercial company.

\section{Logistics}

The tissue bank at Peterborough has succeeded only as a result of commitment, determination, hard work, and enthusiasm driven from the department of histopathology, with the involvement of many individuals including biomedical scientists, consultant medical staff, junior doctors, nurses, ward clerks, theatre staff, porters, senior managers, and executive directors in the trust. It is our experience that the patients have been very positive about the tissue bank, with only three of those approached refusing to sign. One patient spoke very poor English and was unable to understand, another was extremely deaf, and a third patient refused because he thought we were going to transplant his diseased colon into someone else. The multistep process, from identification of potential tissues from operation lists through obtaining consent to dispatch of samples to a commercial biomedical company, is not always smooth and requires proper coordination. This is done by staff in the histopathology department which has necessitated employment of an extra biomedical scientist and, more recently, research nurses in order that the tasks can be completed during the normal working day when most of the hospital surgical activity takes place.

Consultant surgeons are not inconvenienced by the arrangements; they are supportive and with one exception have allowed us access to their patients. We respect the view of one surgeon who objects fundamentally to asking patients to donate tissue that is surplus 
to diagnostic requirements and we do not approach patients on that firm. Some junior doctors have also refused to cooperate, one insisting on a fee.

\section{The future}

We have had inquiries from many healthy people who wish to donate their bodies for biomedical research after death. This is also actively promoted by various animal welfare groups. ${ }^{2}$ At the same time our commercial collaborators need to examine a range of tissue from single donors. In response to this demand we have developed a further set of information sheets and a consent form for collection of human tissue at necropsy examination. These papers, which meet the legal requirements of the Human Tissue Act 1961, have also been approved by the local research ethics committee. We now have a register of potential "whole body donors." Some of these people live many miles away from Peterborough which, combined with the need to collect tissue as soon as possible after death, creates considerable logistical problems. However, it has been possible to obtain viable tissue samples legally and ethically on a Friday evening within 24 hours of death from a patient who was three hours away by road. Many of the potential donors had already contacted their local hospitals and been unable to get a helpful response. It is hoped with the arrangements that are now in place, we will be able to carry out the wishes of the potential "whole body donors" in an ethical and acceptable way that will further enhance the long term standing of the Peterborough Tissue bank.

In publishing the activities of the Peterborough tissue bank we hope to encourage other NHS Trusts to consider a similar venture with the ultimate aim of developing a collaborative national network to service the needs of commercial, university, and NHS research. To ensure that legal, ethical, and quality issues conform to strict minimum standards we support the Nuffield report recommendation that there should be a national register of tissue banks. As the collection of human tissue is largely confined to NHS hospitals it would seem appropriate that this function be undertaken by the NHS executive or the Department of Health.
The main reason for developing the tissue bank was to help forge links with the commercial sector, where we are able to offer allied histopathology services through PCPS. In the recent past the future of NHS funded pathology laboratories has been subject to uncertainty ${ }^{1112}$ and our initiative was begun at a time when several were being run, with varying degrees of success, by private companies including large pharmaceutical firms. We considered that the best way to survive was to be in a position to collaborate with the commercial sector on our terms rather than theirs. Although a change of government has taken some of the pressure away, there is still a drive for greater efficiency in NHS laboratories and capital investment is barely sufficient to maintain the service. Additional income generated by collaboration with the private sector as a result of contacts initially made through the tissue bank has enabled us to invest in laboratory equipment and in our staff as well as providing new enthusiasm and opportunity.

We look forward to continued commercial collaboration but it is important to stress that we do not lose sight of the fact that our laboratory exists primarily to provide high quality diagnostic services to NHS patients - a point which is clearly stated on our consent forms.

1 Coleman RA, Baxter GS. Drug discovery through focus on human biology. In; van Zutphen LFM, Balls M, eds. Animal alternatives, welfare and ethics. Developments in animal and

Animal Aid. Human Tissue: the neglected resource. Tonbridge: Animal Aid. Humal Aid 1997

Coghlan A. Pioneers cut out animal experiments. New Coghlan A. Pioneers
Scientist 1996;151:4.

4 Royal College of Pathologists. Retention and storage of pathological records and archives. London: Royal College of Pathologists, 1995.

5 Nuffield Council on Bioethics. Human tissue: ethical and legal issues. London: Nuffield Council on Bioethics 1995

6 Royal College of Physicians. Guidelines on the practice of ethics committees in medical research involving human subjects. London: Royal College of Physicians, 1990.

7 Start RD, Brown W, Bryant RJ, et al. Ownership and uses of human tissue: does the Nuffield bioethics report accord with opinion of surgical patients? BMF 1996;313:1366-8.

8 Brahams D. My kidney as property. Lancet 1998;352:166.

9 Moore $v$ Regents of the University of California (1990), 793P2d479.

10 NHS Executive. Costing for contracting manual. Leeds: NHS Executive, 1993.

11 Whitby LG, Bird CC, Collee JG, et al. Consequences of the provision of laboratory services for the National Health Service by commercial firms; a view from the University sector. F Clin Pathol 1990;43:441-4.

12 Shanks JM. Consequences of the provision of laboratory services for the National Health Service by commercial firms; a view from the private sector. F Clin Pathol 1990;43: $525-6$. 